\title{
Use and accessibility of health and medication information sources among pharmacy students during their community pharmacy internship
}

\section{Pitkä, Katja}

2018-08

Pitkä , K , Airaksinen , M \& Pohjanoksa-Mäntylä , M 2018 , ' Use and accessibility of health and medication information sources among pharmacy students during their community pharmacy internship ', Currents in Pharmacy Teaching and Learning , vol. 10 , no. 8 , pp. 1041-1047 . https://doi.org/10.1016/j.cptl.2018.05.010

http://hdl.handle.net/10138/309193

https://doi.org/10.1016/j.cptl.2018.05.010

cc_by_nc_nd

acceptedVersion

Downloaded from Helda, University of Helsinki institutional repository.

This is an electronic reprint of the original article.

This reprint may differ from the original in pagination and typographic detail.

Please cite the original version. 
Use and accessibility of health and medication information sources among pharmacy students during their community pharmacy internship

Katja Pitkä*, M.Sc. (Pharm) [Corresponding Author]

Division of Pharmacology and Pharmacotherapy, Faculty of Pharmacy

University of Helsinki.

P.O. Box 56 (Viikinkaari $5 \mathrm{E})$

00014 University of Helsinki

Finland

Phone.: +3580503180270

katja.pitka@helsinki.fi

Marja Airaksinen, Ph.D.

Division of Pharmacology and Pharmacotherapy, Faculty of Pharmacy

University of Helsinki.

P.O. Box 56 (Viikinkaari 5 E)

00014 University of Helsinki

Finland

Phone.: +358 0504480961

maria.airaksinen@helsinki.fi

Marika Pohjanoksa-Mäntylä, Ph.D.

Division of Pharmacology and Pharmacotherapy, Faculty of Pharmacy

University of Helsinki

P.O. Box 56 (Viikinkaari $5 \mathrm{E}$ )

00014 University of Helsinki

Finland

Phone.: +3580504480976

marika.pohjanoksa@helsinki.fi 


\section{Abstract}

Introduction: Evidence-based health and medication information (HMI) sources and databases have a growing importance in daily professional practice in community pharmacies. Previous research suggests that students learn practical skills at the workplace through self-directed learning and practical experience rather than formal training. Thus, pharmacy internship is a key in ensuring pharmacy students' competency to use HMI sources and databases. This study assessed what HMI sources pharmacy students had used and accessible during their first internship in community pharmacies in Finland.

Methods: The data were collected as part of the obligatory assignments of the $2^{\text {nd }}$ year pharmacy students at the University of Helsinki during their first 3-month internship in a community pharmacy in $2013(n=152$, response rate $100 \%)$.

Results: The most commonly used HMI sources during the first internship period were electronic product-specific databases assisting in medication counselling, such as the checklist type generic prescription medication information database integrated into pharmacy prescription processing system, used daily by $74 \%$ of the students having access to the database $(n=121)$. Databases assisting in medication reviews were less commonly used although they were available in the majority of the pharmacies.

Discussion and conclusion: Although the majority of students had access to a wide range of $\mathrm{HMI}$ sources and databases during their internship, the actual use of sources other than product-specific medication information was limited, particularly the use of databases in assisting in medication reviews. It is important to facilitate their use in the second internship to acquire competences needed for their further use after graduation.

Key words: Health information; Medication information; Medication information sources; Pharmacy education; Pharmacy internship; Experiential learning

\section{Conflict of interest}

The authors declare no conflicts of interest. 


\section{Role of funding}

This research did not receive any specific grant from funding agencies in the public, commercial, or not-for-profit sectors.

\section{INTRODUCTION}

Availability of evidence-based health and medication information (HMI) is essential in all healthcare settings for rational drug therapy. ${ }^{1,2}$ Availability of $\mathrm{HMI}$ needs to be accompanied by competency to use HMI sources and databases, which are increasingly in electronic formats, facilitating their prospective effective use in clinical practice. ${ }^{3}$ These competencies can be acquired through undergraduate and continuing education and in-house training. Internships and workplace learning experiences in authentic workplace settings are valuable for undergraduate students for learning professional skills, such as using HMI sources. ${ }^{4,5,6}$

Community pharmacists are important healthcare team members in medication management of ambulatory care patients, particularly in medication counseling and identifying, solving, and preventing medication-related problems. ${ }^{7,8}$ Community pharmacies have several clinically relevant, up-to-date and evidence-based HMI sources to support these tasks. ${ }^{3,9}$ The HMI sources can be classified as: 1) product-specific medication information sources based on manufacturer provided information approved by regulatory agencies (e.g., summaries of product characteristics and package leaflets within European Union); 2) electronic HMI information systems that combine information from different databases and assist in clinical medication reviews; and 3) current care guidelines and other medical information accessible online (Table 1).

In Finland, the majority of the above mentioned HMI sources, used in community pharmacies, are the same used throughout health care (both inpatient and outpatient care). During the obligatory internship included in the pharmacy undergraduate curriculum in Finland, pharmacy students complete learning assignments that deepen their theoretical knowledge and develop their skills to use different $\mathrm{HMI}$ sources in practice. ${ }^{10,11}$ However, little is known whether these efforts will lead to the actual use of $\mathrm{HMI}$ sources during the internship, and thus, will prepare students for using them actively after graduation. 
The aim of this study was to identify the HMI sources accessible and actually used by pharmacy students during their first internship in community pharmacies in Finland. Even though this study has been conducted in Finland, the researched issue is global as digitalization in healthcare will dramatically change working patterns of all healthcare providers, including community pharmacists.

Finland has a 2-tier university training program for pharmacists consisting of BSc and MSc degrees, which is in line with the Bologna Process for harmonizing higher education in the European Union (EU). ${ }^{11-14}$ The BSc (Pharm) degree consists of 180 European Credit Transfer System (ECTS) credits and takes 3 years to complete. The MSc (Pharm) degree takes an additional 2 years to complete (total 300 ECTS credits), including a Master's Thesis (40 credits). According to EU regulations, one of the pharmacists' competency areas is medication information and medication counseling. ${ }^{15}$ Thus, teaching about HMI sources and practices, including medication counseling skills have been integrated into pharmacy education throughout the curriculum in Finland. ${ }^{16,17}$ During the didactic studies in the University, pharmacy students acquire basic knowledge and competencies on how to use different $\mathrm{HMI}$ sources. These competencies include: designing and executing basic search strategies; identification of relevant information; critical evaluation of information; and making use of $\mathrm{HMI}$ in medication-related problem solving and counseling patients. ${ }^{15,16}$ For that purpose, students' learning on how to use HMI sources is integrated throughout the studies they must complete before their internship (Table 2). Their HMI knowledge and skills are deepened during their obligatory 6-month internship (30 ECTS credits), which is an essential part of the pharmacy curriculum in the EU, and in Finland. ${ }^{11,15,18}$

The internship can be taken in a community pharmacy open to the public (minimum 3 months/15 ECTS credits), or in a hospital under supervision of that hospital's pharmaceutical department (maximum 3 months $/ 15$ credits).${ }^{15}$ In Finland, the internship is divided into two 3-months periods during BSc (Pharm) studies, one at the end of the second year and one during the spring semester of the third year (Figure 1). The internship is carried out in close collaboration with the university and the teaching pharmacies. ${ }^{11,19}$ The University of Helsinki, one of the two major pharmacy schools in Finland, has 332 community pharmacies and 21 hospital pharmacies as training pharmacies for an annual volume of approximately 350 students completing the internship (total number of community pharmacies in Finland was 617, and the number of hospital pharmacies 24, in June 2013 when the study was 
conducted). The learning objectives of the internship are designed to facilitate learning in key areas of pharmaceutical practice in teaching pharmacies. ${ }^{19}$ In addition to facilitating learning, these assignments assure and standardize minimum quality of internship. The first 3-month internship period is for learning basic skills needed in pharmaceutical tasks in community and hospital pharmacy settings (e.g. in dispending, compounding and patient counseling). During both internship periods, students reflect on their learning through reflective assignments. ${ }^{11}$ The assignments are organized as workbooks ${ }^{20}$ covering the core contents of each internship period.

\section{METHODS}

Data collection and analysis

The data were collected as part of the obligatory self-reflective assignment for 2nd-year pharmacy students at the University of Helsinki after completing their first 3-month internship in a community pharmacy in 2013. ${ }^{20}$ An obligatory assignment with a link to an electronic evaluation form (eForm version 3) was included in the students' workbook. ${ }^{11,20}$ As an assignment, the students were instructed to report the use of $\mathrm{HMl}$ sources during the internship via the eForm within two weeks of the completion of their internship. The primary aim of the assignment was to enable students to evaluate their learning to use HMl sources, which had started in the university, and was planned to continue during the internship. The secondary aim was to help the faculty get an understanding of the students' competency level reached in using HMI sources, by the end of the first internship period.

In the assignment, the students were asked to report what HMI sources were available in the teaching pharmacy and how often they used each of the available sources during the internship. The assignment included a structured list of $\mathrm{HMI}$ sources available in Finland for health care professionals and community pharmacists at the time of the internship (Table 1). The list was developed by updating a list used in a previous study on practicing pharmacists' utilization of different medication information sources in community pharmacies. ${ }^{21}$ The special focus was on the use of electronic HMI sources during the internship. HMI sources were classified into the following four categories based on their content and purpose of use as described in the Introduction: 1) Product-specific medication information sources, 2) 
Table 1. Health and Medicines Information (HMI) Sources Available for Health Care Professionals and Routinely Accessible in Community Pharmacies in Finland.

\begin{tabular}{|c|c|c|}
\hline $\begin{array}{l}\text { Health and Medicines } \\
\text { information source }\end{array}$ & Description & Provider \\
\hline $\begin{array}{l}\text { Summaries of product } \\
\text { characteristics (SPCs) }\end{array}$ & $\begin{array}{l}\text { A statutory key part of the marketing authorization documentation } \\
\text { of pharmaceutical products and herbal medicinal products } \\
\text { authorized in the European Union. SPC information is targeted to } \\
\text { healthcare professionals as basic product-specific information. }\end{array}$ & $\begin{array}{l}\text { SPCs are produced by drug companies, approved by authorities, available } \\
\text { online via Finnish Medicines Agency Fimea } \\
\text { (http://www.fimea.fi/medicines/fimeaweb) }\end{array}$ \\
\hline $\begin{array}{l}\text { Medicines information } \\
\text { databases in the National } \\
\text { Health Portal Terveysportti by } \\
\text { the Finnish Medical Society } \\
\text { Duodecim }\end{array}$ & $\begin{array}{l}\text { Includes information on authorized and commonly used } \\
\text { unauthorized pharmaceutical products and herbal medicinal } \\
\text { products. Database includes also information about medicines } \\
\text { prices and reimbursements. }\end{array}$ & $\begin{array}{l}\text { Terveysportti Health Portal by The Finnish Medical Society Duodecim } \\
\text { (http://www.duodecim.fi/web/english/home) }\end{array}$ \\
\hline $\begin{array}{l}\text { Finnish Pharmaceutical } \\
\text { Reference Book } \\
\text { (Pharmaca Fennica®) }\end{array}$ & $\begin{array}{l}\text { Includes brief versions of SPCs, information on medicines prices } \\
\text { and reimbursements, anatomic-therapeutic-chemical (ATC) } \\
\text { classification of medicines. }\end{array}$ & $\begin{array}{l}\text { Pharmaceutical Information Center, a medicines information company } \\
\text { owned by Pharma Industry Finland } \\
\text { (http://www.laaketietokeskus.fi/en) }\end{array}$ \\
\hline Package leaflets (PLs) & $\begin{array}{l}\text { Statutory information on the authorized medicinal products and } \\
\text { herbal medicinal products based on SPCs targeted to medicine } \\
\text { users. }\end{array}$ & $\begin{array}{l}\text { PLs are produced by drug companies, approved by authorities, available } \\
\text { as package inserts and online via Finnish Medicines Agency Fimea } \\
\text { (http://www.fimea.fi/medicines/fimeaweb) and Lääketietokeskus }\end{array}$ \\
\hline $\begin{array}{l}\text { Database to support } \\
\text { medication counseling } \\
\text { (YA-Helppi®) }\end{array}$ & $\begin{array}{l}\text { Similar database with Tietotippa }{ }^{\circledR} \text {, but available only in the } \\
\text { University Pharmacy owned by University of Helsinki. }\end{array}$ & $\begin{array}{l}\text { University Pharmacy } \\
\text { (http://www.yliopistonapteekki.fi/fi/apteekkipalvelut/pages/english.aspx) }\end{array}$ \\
\hline $\begin{array}{l}\text { Finnish Medicines Agency's } \\
\text { web search for authorized } \\
\text { medicinal products and herbal } \\
\text { medicinal products } \\
\text { (FimeaWeb) }\end{array}$ & $\begin{array}{l}\text { Free search service containing information on authorized } \\
\text { medicinal products and herbal medicinal products intended for } \\
\text { human and veterinary use in Finland. }\end{array}$ & $\begin{array}{l}\text { Finnish Medicines Agency (Fimea) } \\
\text { (http://www.fimea.fi/medicines/fimeaweb) }\end{array}$ \\
\hline $\begin{array}{l}\text { Social Insurance Institution's } \\
\text { web search for medicinal }\end{array}$ & $\begin{array}{l}\text { Information about prices, reimbursements and equivalent } \\
\text { products of medicines, clinical nutrients and emollients marketed } \\
\text { in Finland. }\end{array}$ & $\begin{array}{l}\text { Social Insurance Institution (Kela) } \\
\text { (http://www.kela.fi/web/en) }\end{array}$ \\
\hline
\end{tabular}




\begin{tabular}{|c|c|c|}
\hline $\begin{array}{l}\text { products and their } \\
\text { reimbursement rules }\end{array}$ & & \\
\hline $\begin{array}{l}\text { European Medicines } \\
\text { Agency's search for } \\
\text { authorized medicinal products } \\
\text { and herbal medicinal products }\end{array}$ & $\begin{array}{l}\text { European public assessment reports (EPARs) and SPCs for } \\
\text { human medicines, public-friendly summaries in question-and- } \\
\text { answer format and the package leaflets. }\end{array}$ & $\begin{array}{l}\text { European Medicines Agency (EMA) } \\
\text { (http://www.ema.europa.eu/ema/index.jsp?curl=pages/includes/medicine } \\
\text { s/medicines_landing_page.jsp) }\end{array}$ \\
\hline Martindale $®$ & $\begin{array}{l}\text { The complete drug reference book containing information on } \\
\text { medicines used throughout the world, including details of } \\
\text { proprietary preparations and disease treatment reviews. }\end{array}$ & $\begin{array}{l}\text { Pharmaceutical Press by the Royal Pharmaceutical Society of Great } \\
\text { Britain (https://www.medicinescomplete.com/mc/martindale/) } \\
\text { Available online for students }\end{array}$ \\
\hline \multicolumn{3}{|c|}{ Tools and databases assisting in medication reviews } \\
\hline $\begin{array}{l}\text { Database to support clinical } \\
\text { decision making of physicians } \\
\text { (Physician's database } 囚 \text { ) }\end{array}$ & $\begin{array}{l}\text { Includes guidelines and evidence summaries with links to } \\
\text { Cochrane reviews, also images and voices. Available in Finnish } \\
\text { health portal Terveysportti. }\end{array}$ & $\begin{array}{l}\text { The Finnish Medical Society Duodecim } \\
\text { (http://www.duodecim.fi/web/english/home) }\end{array}$ \\
\hline $\begin{array}{l}\text { Database to support nursing } \\
\text { work } \\
\text { (Nursing database }(\text { ) }\end{array}$ & $\begin{array}{l}\text { Includes guidelines to support daily nursing work (eg. diabetes } \\
\text { care and resuscitation). Available in Finnish health portal } \\
\text { Terveysportti. }\end{array}$ & $\begin{array}{l}\text { The Finnish Medical Society Duodecim } \\
\text { (http://www.duodecim.fi/web/english/home) }\end{array}$ \\
\hline $\begin{array}{l}\text { Database for use of medicines } \\
\text { in renal failure (Renbase }()\end{array}$ & $\begin{array}{l}\text { Includes information to support decision-making concerning the } \\
\text { pharmacotherapy of patients with renal failure. Available in } \\
\text { Finnish health portal Terveysportti. }\end{array}$ & $\begin{array}{l}\text { The Finnish Medical Society Duodecim } \\
\text { (http://www.duodecim.fi/web/english/home) }\end{array}$ \\
\hline $\begin{array}{l}\text { Database for use of medicines } \\
\text { during pregnancy and } \\
\text { lactation (Gravbase and } \\
\text { Lactbase }(\text { ) }\end{array}$ & $\begin{array}{l}\text { Database to support decision-making concerning } \\
\text { pharmacotherapy during pregnancy and lactation. Available in } \\
\text { Finnish health portal Terveysportti. }\end{array}$ & $\begin{array}{l}\text { The Finnish Medical Society Duodecim } \\
\text { (http://www.duodecim.fi/web/english/home) }\end{array}$ \\
\hline $\begin{array}{l}\text { Database on herbal medicines } \\
\text { (Herbalbase } \AA)\end{array}$ & $\begin{array}{l}\text { Includes information on efficacy and safety of herbal medicines. } \\
\text { Available in Finnish health portal Terveysportti. }\end{array}$ & $\begin{array}{l}\text { The Finnish Medical Society Duodecim } \\
\text { (http://www.duodecim.fi/web/english/home) }\end{array}$ \\
\hline $\begin{array}{l}\text { Databases for interactions and } \\
\text { adverse drug reactions }\end{array}$ & $\begin{array}{l}\text { Databases including information on interactions and adverse drug } \\
\text { reactions, e.g. SFINX-Pharao. }\end{array}$ & $\begin{array}{l}\text { For example the Finnish Medical Society Duodecim } \\
\text { (http://www.duodecim.fi/web/english/home }\end{array}$ \\
\hline $\begin{array}{l}\text { Medication review tool for } \\
\text { community pharmacies } \\
(\text { Salko®) }\end{array}$ & $\begin{array}{l}\text { Database assisting in medication reviews which identifies } \\
\text { potentially inappropriate medications for aged people, includes } \\
\text { information on pharmacokinetic and pharmacodynamic } \\
\text { interactions, anticholinergic, sedative and serotonergic effects of } \\
\text { medicines. }\end{array}$ & $\begin{array}{l}\text { Association of Finnish Pharmacies (AFP) } \\
\text { (provided by The Finnish Medical Society Duodecim) }\end{array}$ \\
\hline $\begin{array}{l}\text { Database of medication } \\
\text { suitable for the elderly } \\
(\text { Meds } 75+)\end{array}$ & $\begin{array}{l}\text { Includes information to support clinical decision-making } \\
\text { concerning the medication of the aged (> } 75 \text { years). The database }\end{array}$ & $\begin{array}{l}\text { Finnish Medicines Agency (Fimea) } \\
\text { (http://www.fimea.fi/web/en/databases_and_registeries/medicines_infor } \\
\text { mation/database_of_medication_for_the_elderly) }\end{array}$ \\
\hline
\end{tabular}




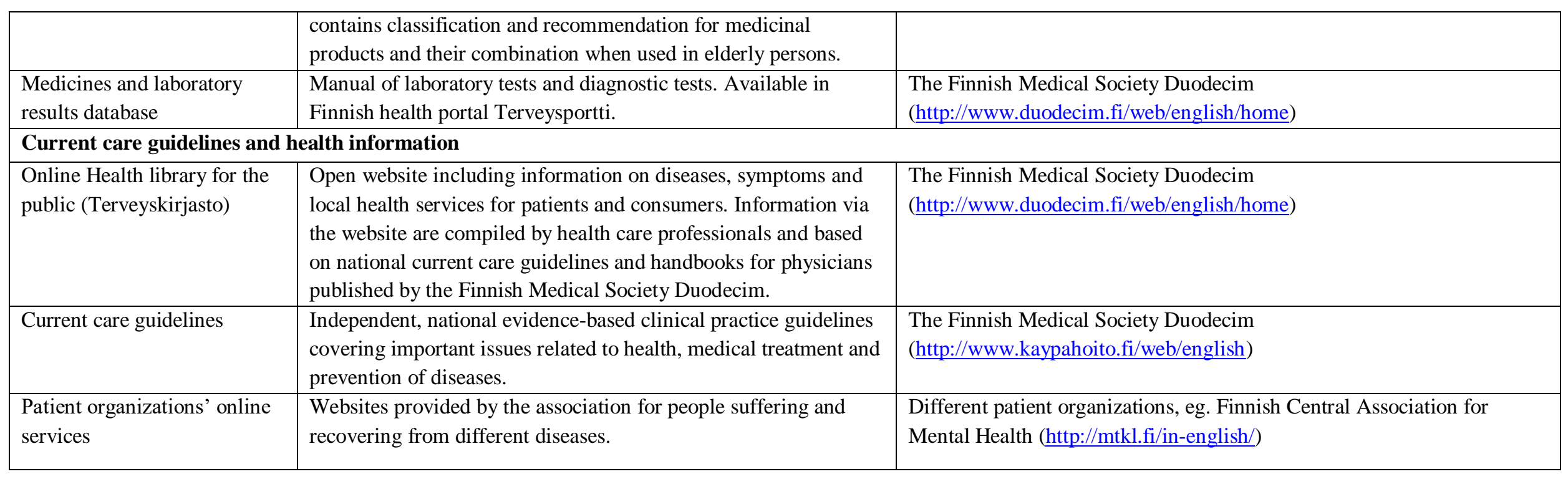


Table 2. The Courses that Students Must Complete at the University Before the Internship Periods.

\begin{tabular}{|c|c|}
\hline $\begin{array}{l}\text { Professional study to be completed for the first } \\
\text { internship period }\end{array}$ & $\begin{array}{l}\text { Professional study to be completed for the second } \\
\text { internship period }\end{array}$ \\
\hline $\begin{array}{l}\text { - } \quad \text { Systematic Pharmacology, } 12 \mathrm{cr} \\
\text { - } \quad \text { Pharmacotherapy I, } 3 \mathrm{cr} \\
\text { - } \quad \text { Biopharmaceutics and Pharmacokinetics, } \\
\text { - } \quad \text { Cectures, } 5 \mathrm{cr} \text { and Laboratory work I, } 1 \mathrm{cr} \\
\text { - Pharmacy + Communication Skills, } 3 \mathrm{cr} \\
\text { - Pharmacy Practice, } 4 \mathrm{cr} \\
\text { - } \quad \text { Pharmaceutical Legislation, } 3 \mathrm{cr} \\
\text { - } \quad \text { Pharmaceutical Technology, Laboratory work, } 8 \\
\text { - }\end{array}$ & $\begin{array}{ll}\text { - } & \text { Pharmacotherapy II, } 3 \mathrm{cr} \\
\text { - } & \text { Biopharmaceutics and Pharmacokinetics, } \\
& \text { Laboratory II, } 1 \mathrm{cr} \\
\text { - } & \text { Medicines in Health Care, } 5 \mathrm{cr} \\
\text { - } & \text { Basics in Phytotherapy, } 3 \mathrm{cr}\end{array}$ \\
\hline
\end{tabular}

* One ECTS credit (cr) corresponds to 27 hours of student work. The credits are compatible with the European Credit Transfer System, ECTS. ${ }^{22}$ 


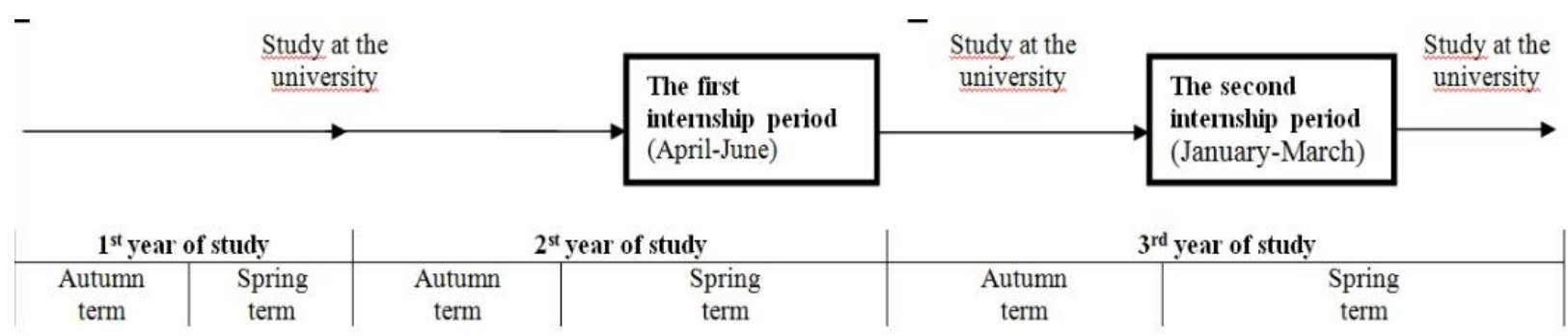

Figure 1. Integration of the Obligatory Internship with Professional Study during Second and Third Year of Studies in the Pharmacy Curriculum in Finland. 
Table 3. Characteristics of the Responding Students and Their Internship Pharmacies $(n=152)$.

\begin{tabular}{|l|c|}
\hline Variable & $\%(\mathbf{n})$ \\
\hline Pharmacy & \\
Privately owned pharmacy & $80(121)$ \\
University Pharmacy & $20(31)$ \\
\hline Size of the pharmacy (prescriptions per year) & \\
$\leq 30000$ & $8(12)$ \\
$30001-60000$ & $18(28)$ \\
$600001-100000$ & $28(42)$ \\
$>100000$ & $46(70)$ \\
\hline Location of the pharmacy (region) & \\
Southern Finland & $82(124)$ \\
Western Finland & $13(20)$ \\
Oulu Region & $4(6)$ \\
Eastern Finland & $1(1)$ \\
Lapland & $1(1)$ \\
\hline
\end{tabular}


Medication review tools and databases, 3) Current care guidelines and health/medical information sources, and 4) Other electronic HMI sources, and medication information centers (Table 1). As background information, the students were asked to provide their name and student ID-number, the teaching pharmacy's annual prescription volume and location. The structured responses were analyzed using the Statistical Package for the Social Sciences software (SPSS version 22). The descriptive statistics are presented as frequencies and percentages.

\section{Ethical considerations}

The study was conducted in accordance with the guidelines of the Finnish National Advisory Board on Research Integrity ${ }^{22}$ and Ethical Review Board in the Humanities and Social and Behavioural Sciences, University of Helsinki. ${ }^{23}$ Based on their instructions, this study was deemed exempt from requiring formal ethics committee approval.

\section{RESULTS}

As the study was based on the obligatory assignment, the overall response rate was $100 \%(n=152)$. The majority $(80 \%)$ of the students carried out their internship in a community pharmacy located in Southern or Western Finland (Table 3). Nearly half $(46 \%)$ of the pharmacies were large pharmacies dispensing more than 100000 prescriptions per year.

Use and Accessibility of Health and Medication Information Sources

The majority of the students had access to the key HMI sources during their internship in the community pharmacy (Figure 2). Students used most commonly product-specific medication information sources (Table 1). The checklist-type generic medication information database integrated into pharmacy prescription processing system, assisting in medication counseling (Tietotippa) was the most referenced source, being used daily by $74 \%$ of the students who had access to the database $(n=121)$. An almost similarly used medication information source was the National Reference Book, containing statutory summaries of product characteristics (SPCs), (used daily by $69 \%$ of the students, $n=105$ ), 
followed by medication information databases provided by The Finnish Medical Society $(60 \%, n=91)$ and statutory package leaflets (PLs) $(53 \%, n=80)$. Of the medication review tools and databases, interaction and adverse drug reaction programs (e.g. SFINX-Pharao) were daily used by $52 \%(n=79)$ of the students, but the database for medicine use in renal failure $(3 \%, n=5)$, the program assisting in reviewing medications of older people $(3 \%, n=5)$ and identifying potentially harmful medications of the aged $(3 \%, n=4)$ were rarely used.

\section{DISCUSSION}

To our knowledge, this is the first study focusing on pharmacy students' use of electronic HMI sources in community pharmacy during their internship. The study complements the information known about HMI sources used by the practicing pharmacists. ${ }^{21,} 24,25$ According to the students, the key HMI sources were accessible in the majority of the teaching pharmacies. Students actively used them during the internship, particularly electronic databases designed to assist in dispensing and medication counseling, while the medication review tools and databases were less commonly used.

Given that the aim of the first internship is to learn basic dispensing and medication counseling skills, databases to support these pharmaceutical tasks are naturally most used. These databases assist students in deepening their knowledge on basic pharmacotherapeutic properties of active ingredients of pharmaceutical products in real life context, and customizing medication-specific information according to each client's needs. Databases, such as a checklist-type generic medication information database integrated into pharmacy prescription processing systems, assist students in identifying clinically important information that needs to be communicated with the client while dispensing. This check-list type database (Tietotippa) seemed to be particularly valuable for the students as it was most widely used of all the accessible databases.

Although the focus in this study was on the second year pharmacy students' use of HMI sources during their internship, the results may also reflect the use of $\mathrm{HMI}$ sources among practicing pharmacists in teaching pharmacies. Previous research has found that product-specific databases are the most used among graduated pharmacists in their daily practice ${ }^{24,25}$ Also our present finding that medication review 
(2)

PRODUCT-SPECIFIC MEDICATION INFORMATION SOURCES Database to support medication counseling in privately owned community pharmacies Finnish Pharmaceutical Reference Book

Medication information databases in the National Health Porta Statutory package leaflets (PLs)

Statutory summaries of product characteristics (SPCS)

Database to support medication counseling in University Pharmacies

Social Insurance Institution's web search for medicinal products

Finnish Medicines Agency's web search for medicinal products The complete drug reference book (Martindale)

European Medicines Agency's web search for medicinal products MEDICATION REVIEW TOOLS AND DATABASES

Databases for interactions and adverse drug reactions

Physician's database

Physician's handbook

Database on medication use during pregnancy and lactation

Database on efficacy and safety of herbal medicines

Medication review tool for community pharmacies

Database on medication use in renal failure

Finnish Medicines Agency's database of medication suitable for the elderly

$$
\text { Nursing database }
$$

Medicines and laboratory results database

CURRENT CARE GUIDELINES AND HEALTH INFORMATION

Online Health library for the public Current care guidelines

Patient organizations' online services

OTHER ELECTRONIC MEDICINES INFORMATION SOURCES

Information data portal for AFP pharmacy network Wholesalers' Online Services

Pharmaceutical Companies' Online Services

MEDICINES INFORMATION CENTERS

University Pharmacy Medicines Information Center

National Medicines Information Call Center

Poison Information Center

Teratology information Center

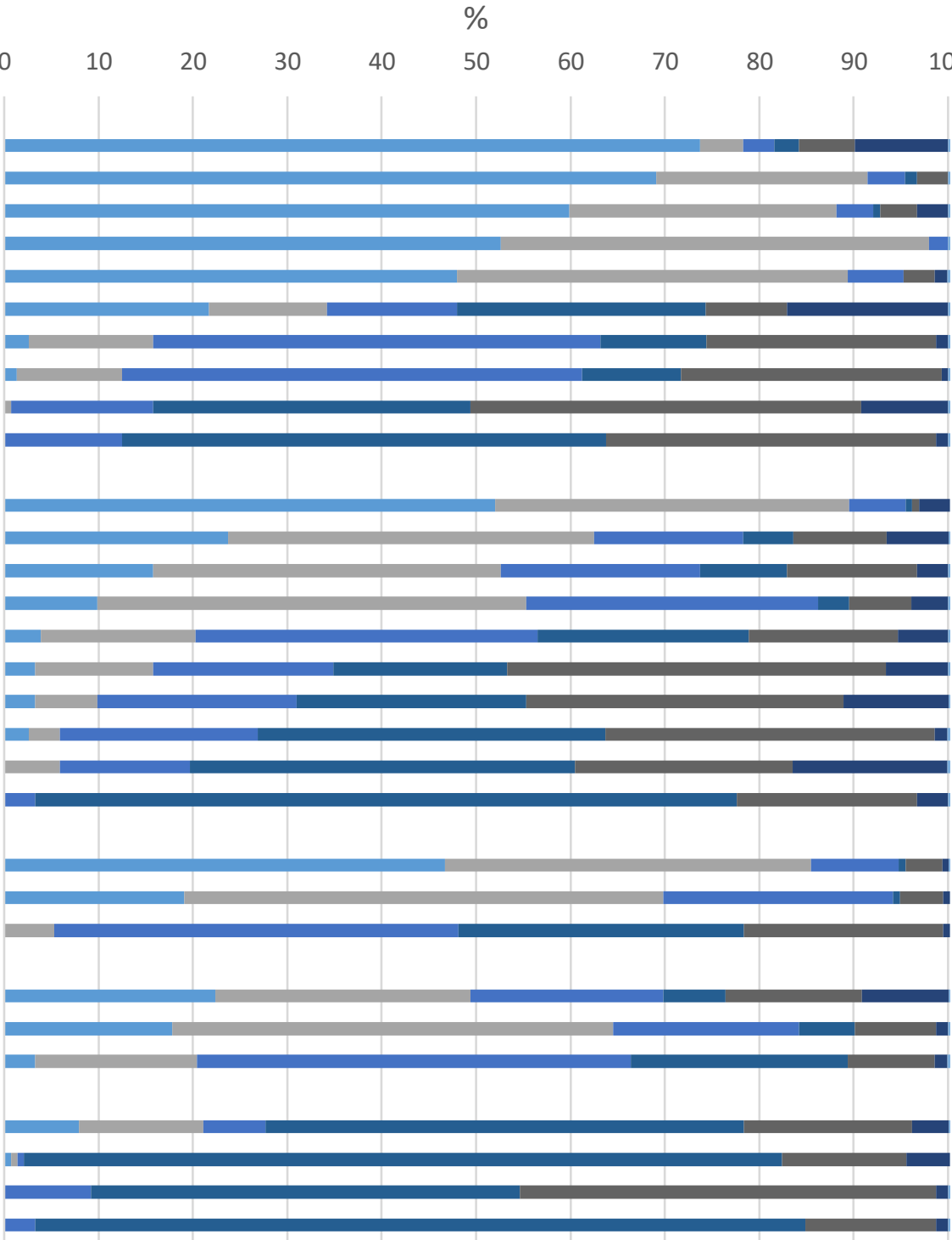

Daily

Not accessible in the pharmacy 
Figure 2. Accessibility and Use of Product Specific Medicine Information Sources, Medication Review Tools and Databases, Current Care Guidelines, Health Information, Other Electronic Medicines Information Sources and Medicines Information Centers among Pharmacy Students ( $\mathrm{n}=152$ ) during Their First Internship in Community Pharmacies.

*Students know, what information the HMI source contains, but they have not used the source in practice. 
tools and databases were less used is in line with previous studies conducted in community pharmacies in Finland. This may be due to the fact that even though installed in almost every pharmacy's prescription processing system, not all practicing pharmacists have been trained to use these tools in daily practice ${ }^{26,27}$ and do not know how to apply the information to patient care.

Medication reviews require clinical competence that community pharmacists do not routinely have in Finland without additional training. ${ }^{28,29}$ This reflects to preceptors' skills to introduce students to use databases containing more clinically oriented pharmacotherapeutic and medical information. ${ }^{19}$ If pharmacy preceptors do not have the skills necessary to utilize these resources, it would be difficult for them to teach students. However, students have received didactic education at the university of different type of databases and their use prior to the internship. Thus, they should know the basics on how to use clinical practice guidelines and medication review databases, which were less used in this study. As teaching and learning are interactive processes that can result in the learning of both teacher and student ${ }^{6}$, pharmacy students can support their preceptors and other pharmacists' competencies in using medication review tools and databases. Further research should be focused on understanding more in detail students and pharmacists' learning processes in acquiring skills needed in more clinically oriented community pharmacy practice.

This study indicates that use of HMI sources in clinical pharmacy practice needs to be taught as a constructive alignment throughout the curriculum, including internship periods to ensure students competency development in practice. After this study was conducted in 2013 , the pharmacy school at the University of Helsinki has started a curriculum reform and new learning assignments on use of $\mathrm{HMI}$ sources in medication counseling and reviews in community pharmacies have been included in the internship periods in order to facilitate learning. ${ }^{14,20}$

Even though the response rate of this study was $100 \%$, the generalizability of the results is limited to teaching pharmacies of the University of Helsinki. However, the study is important for other countries developing their curriculums and educating their students on HMI sources, which is increasingly important in the changing healthcare environment. Based on this study, students had familiarized themselves with and actually used a number of $\mathrm{HMl}$ resources. Future studies may focus on 
assessment of students' actual competency and performance and the usefulness of HMI sources in this respect. Comparative studies after the second internship could show progression of the students' competency. Qualitative research could complement current quantitative research and provide insights in students' HMI seeking behaviors, readiness to use digital resources which are becoming standard practice, and constructing clinical knowledge and skills. Future studies are also needed to evaluate the impact of the ongoing curriculum reform on these learning outcomes.

\section{CONCLUSION}

Although the majority of pharmacy students had access to a wide range of electronic $\mathrm{HMI}$ sources and databases during their internship, the actual use of sources other than product-specific medication information was limited, particularly the use of databases in assisting in medication reviews. It is important to facilitate their use in the second internship to acquire competences needed for the further use of them in the working life after graduation.

\section{ACKNOWLEDGEMENT}

We are grateful to Richard Stevenson (M.Sc.) for linguistic help with the manuscript. 


\section{REFERENCES}

1. Finnish Medication Agency Fimea. Rational use of medication through information and guidance medication information services: current state and the strategy for 2020. Fimea develops, assesses and

informs. Serial publication; 1/2012. Available at: https://www.fimea.fi/documents/160140/1153780/20853_Fimea_KAI_JULKAISUSARJA_Laakeinform aatiostrategia_1_2012_lopullinen_verkkoon.pdf/4c2e20b7-02a9-46e6-83ca-eebc55d2ad8c. Accessed March 26, 2018.

2. Hämeen-Anttila K, Luhtanen S, Airaksinen M, Pohjanoksa-Mäntylä M. Developing a national medication information strategy in Finland - a stakeholders' perspective on the strengths, challenges and opportunities in medication information. Health Policy 2013;111(2):200-205.

3. Westerling A. Information technology development needs in community pharmacies: a strategic approach [Academic dissertation]. University of Helsinki, 2011. Available at: https://helda.helsinki.fi/handle/10138/28196. Accessed March 26, 2018.

4. Kettis $\AA$, Ring L, Gustavsson M, Wallman A. Placement: an underused vehicle for quality enhancement in higher education? Qual in High Educ. 2013;19(1):28-40.

5. Trede F, McEwen C, Kenny A, O'Meara P. Supervisors' experiences of workplace supervision of nursing and paramedic students in rural settings: a scoping review. Nurse Educ Today 2014;34(5):783788.

6. Lave J, Wenger E. Situated learning, Legitimate peripheral participation. Cambridge MA. University of Cambridge Press; 1991.

7. Bell JS, Väänänen $M$, Ovaskainen $H$, Närhi U, Airaksinen M. Providing patient care in community pharmacies: practice and research in Finland. Ann Pharmacother. 2007;41(6):1039-1046. 
8. Noyce PR. Providing patient care through community pharmacies in the UK: policy, practice, and research. Ann Pharmacother. 2007;41(5):861-868.

9. Närhi U, Helakorpi S. Sources of medicine information in Finland. Health Policy 2007;84:51-57.

10. Hyvärinen ML, Tanskanen $\mathrm{P}$, Katajavuori N, Isotalus $\mathrm{P}$. Feedback in patient counselling trainingpharmacy students' opinions. Patient Educ Couns. 2008;70(3):363-369.

11. Pitkä K, Löfhjelm U, Passi S, Airaksinen M. Integration of internship with professional study in pharmacy education in Finland. Am J Pharm Educ. 2014;78(9): Article 173.

12. The Bologna Declaration of 19 June 1999. Joint declaration of the European Ministers of Education. Available

at:

http://media.ehea.info/file/Ministerial_conferences/02/8/1999_Bologna_Declaration_English_553028.p df. Accessed March 26, 2018.

13. Katajavuori N, Hakkarainen K, Kuosa T, Airaksinen M, Hirvonen J, Holm Y. Curriculum reform in Finnish pharmacy education. Am J Pharm Educ. 2009;73(8): Article 151.

14. Katajavuori N, Salminen O, Vuorensola K, Huhtala H, Vuorela P, Hirvonen J. Competence-Based Pharmacy Education in the University of Helsinki. Pharmacy 2017;5(2): Article 29.

15. EU. Directive 2013/55/EU of the European Parliament and of the Council of 20 November 2013 amending Directive 2005/36/EC on the recognition of professional qualifications and Regulation (EU) No 1024/2012 on administrative cooperation through the Internal Market Information System. Available at: http://eur-lex.europa.eu/legal-content/EN/TXT/PDF/?uri=CELEX:32013L0055\&from=EN. Accessed March 26, 2018.

16. Faculty of Pharmacy, University of Helsinki. The learning outcomes for the Bachelor and Master of Science

in pharmacy degrees.

Available

at: 
https://www.helsinki.fi/sites/default/files/atoms/files/2016_396_osaamistavoitteet_29_3_2016_en.pdf. Accessed March 26, 2018.

17. Faculty of Pharmacy, University of Helsinki. Course catalogue. Available at: https://weboodi.helsinki.fi/hy/vl_kehys.jsp?MD5avain=\&Opas=5405\&Org=41547372\&vl_tila=1\&AukAi kMaar=1\&Kieli=6. Accessed March 26, 2018.

18. International Pharmaceutical Federation (FIP). Counselling, concordance and communication Innovative education for pharmacists. Edited by Pohjanoksa-Mäntylä M, Yeung S.S.T, Puumalainen I, $\begin{array}{llll}\text { Airaksinen } & \text { M. FIP and IPSF; 2012. Available at: }\end{array}$ https://fip.org/files/fip/HaMIS/fip_ipsf_pce_2nd_2012.pdf. Accessed March 26, 2018.

19. Löfhjelm U, Pitkä K, Passi S, Airaksinen M. Preceptors' need for support in tutoring pharmacy students in Finnish community pharmacies. Innov Pharm. 2016;7(4):Article 8.

20. Faculty of Pharmacy, University of Helsinki. Työ opiksi! [Internship assignments organized as workbooks]. Available at: https://www.helsinki.fi/fi/ohjelmat/kandi/farmaseutinkoulutusohjelma/opiskelu/apteekkiharjoittelu\#section-42697. Accessed March 26, 2018.

21. Kuitunen S, Holmström A-R, Airaksinen M, Pohjanoksa-Mäntylä M, Peura S, Teinilä T. Medication safety in Finnish community pharmacies: Baseline in the beginning of Apila Program in 2012. Dosis 2014;30(3):164-176 [English summary]. Available at: http://elektra.helsinki.fi/se/d/07834233/30/3/laakitys.pdf. Accessed March 26, 2018.

22. Finnish Advisory Board on Research Integrity. Ethical principles of research in the humanities and social and behavioural sciences and proposals for ethical review. Helsinki 2009. Available at: http://www.tenk.fi/en. Accessed March 26, 2018. 
23. Ethical Review Board in the Humanities and Social and Behavioural Sciences, University of Helsinki. Instructions for researchers. Available at: https://www.helsinki.fi/en/ethical-review-board-in-thehumanities-and-social-and-behavioural-sciences. Accessed March 26, 2018.

24. Kuitunen S. Medication safety in Finnish community pharmacies at the beginning of Apila project in 2012 [Master's thesis]. University of Helsinki, 2014 [English summary]. Available at: https://helda.helsinki.fi/handle/10138/177345. Accessed March 26, 2018.

25. Hakala T. Pharmacies involving in risk management of medications - modes of operation, tools and knowledge in Finnish pharmacies [Master's thesis]. University of Helsinki, 2016. [English summary].

26. Toivo TM, Mikkola JA, Laine K, Airaksinen M. Identifying high risk medications causing potential drug-drug interactions in outpatients. Res Social Adm Pharm. 2016;12(4):559-68.

27. Westerling AM, Haikala VE, Bell JS, Airaksinen MS. Logistics or patient care: which features do independent Finnish pharmacy owners prioritize in a strategic plan for future information technology systems? J Am Pharm Assoc. 2010;50(1):24-31.

28. Leikola S, Tuomainen L, Ovaskainen H, Peura S, Sevón-Vilkman N, Tanskanen P, Airaksinen M. Continuing Education Course to Attain Collaborative Comprehensive Medication Review Competencies. Am J Pharm Educ. 2009;73(6): Article 108.

29. Leikola S. Development and application of comprehensive medication review procedure to community-dwelling elderly. [Academic dissertation]. University of Helsinki, 2012. https://helda.helsinki.fi/handle/10138/30203; Accessed March 26, 2018. 